\title{
GLOSSOLALIA: DIVINE SPEECH OR MAN-MADE LANGUAGE? A PSYCHOLOGICAL ANALYSIS OF THE GIFT OF SPEAKING IN TONGUES IN THE PENTECOSTAL CHURCHES IN BOTSWANA
}

\author{
James N Amanze and Tino Shanduka \\ Department of Theology and Religious Studies, \\ Faculty of Humanities, University of Botswana \\ amanzejn@mopipi.ub.bw
}

\section{ABSTRACT}

Glossolalia is a very important element in the life of Pentecostal Churches and is at the centre of their spirituality. This paper examines the gift of speaking in tongues from a psychological perspective in order to find out what psychologists say about this very important gift of the Holy Spirit. The paper begins by looking at the history of speaking in tongues in the Church from the day of Pentecost and how it has become the symbol of God's presence in the life of believers in Pentecostal Churches in Botswana today. The paper interrogates glossolalia on whether it is divine language or human language spoken by people who are emotionally charged. This research was undertaken in order to understand glossolalia better, since it is a contested area not only among Christians but also in other world religions where this phenomenon is widely manifested. The present work shows that while theologians are justified to consider glossolalia as divine language, there are indications that in some instances speaking in tongues can be a result of anxiety and human attempts to prove that the Holy Spirit is truly present in one's spiritual life. This conclusion has been reached especially in cases where it has been found that glossolalia is a learned language.

Key words: Pentecostal Churches; glossolalia; divine-speech; speaking in tongues; man-made language; ecstatic utterance; anxiety, depression; healing; kingdom of God; kingdom of the devil.

\section{UNISA $\cong$}

Studia Historiae Ecclesiasticae Volume 41 | Number 1 | 2015 pp. 3-19
DOI: http://dx.doi.org/10.17159/2412-4265 /2015/v41n1a2 Print ISSN 1017-0499 | Online 2374-3689 (c) 2015. Studia Historiae Ecclesiasticae 


\section{Introduction}

This paper examines the phenomenon of speaking in tongues from a psychological perspective in Pentecostal Churches in Botswana. The main objective of the paper is to investigate whether speaking in tongues is 'divine speech' or if it is merely a man-made language spoken by emotionally charged people. This investigation is warranted because glossolalia normally takes place in the context of highly charged emotional prayer meetings, with abundant music, loud prayers and an expectation that speaking in tongues will happen. The after effects of speaking in tongues, is a feeling of euphoria at having had the sacred experience. ${ }^{1}$ In order to achieve the objective, this paper uses a psychology of religion theoretical framework as expounded by Crapps (1986) in his book titled An introduction to psychology of religion. ${ }^{2}$ In this regard, the paper raises a number of psychological questions. It interrogates, in the first place, why this phenomenon occurs. In other words, what happens in the mind when a person speaks in tongues? The paper is also interested to find out what kind of people are prone to speaking in tongues and what kind of circumstances lead people to speak in tongues.

\section{From the periphery to the centre of religious worship}

Kildahl (1972) in Psychology of speaking in tongues observed that until the late 1950 s the practice of speaking in tongues was confined to a few extreme, theological conservative religious sects. ${ }^{3}$ The context in which speaking in tongues occurred was generally ecstatic - even hysteric. Then gradually the gift of speaking in tongues began also to appear in mainline Protestant Churches. Today the practice of speaking in tongues is found among Episcopalians in the United States of America, among Evangelical Anglicans, Lutherans, Presbyterians, Congregationalists and even Roman Catholics. ${ }^{4}$

We embarked on this research because we were intrigued by the fact that glossolalia or speaking in tongues is at the core of Pentecostal-charismatic Christianity and yet it is heavily contested not only among Christians of different denominations, but also among charismatics themselves. Glossolalia is also contested by a number of psychologists who view the gift of speaking in tongues as a pathological phenomenon, that is to say, it is part of abnormal behaviour. It is these views, among other things, that made us carry out a critical study of this religious phenomenon. The study purports to examine to what extent glossolalia can be considered the work of God through the Holy Spirit and not deviant behaviour as the majority of psychologists claim it to be.

A very stringent study, which was carried out in the USA by Kildahl (a clinical psychologist) and Qualben (MD Psychiatrist), attempted to discover the real nature 
of the language of those who speak in tongues, commonly known as glossolalia. ${ }^{5}$ According to The new Penguin English dictionary, the word glossolalia is derived from two Greek words namely ' $g l o s s a$ ' which means 'tongue' and 'lalia' from 'lalein' meaning to 'chatter' or to 'talk'. ${ }^{6}$ The same dictionary defines glossolalia simply as a phenomenon of ecstatic speaking in usually incomprehensible language, especially in evangelical Christianity or as a symptom of a psychiatric or psychological disorder. ${ }^{7}$

The phenomenon of glossolalia as incomprehensible language was detected by Kildahl and Qualben in their scientific investigation of speaking in tongues. By means of observation they noted that a certain Mrs Rogers standing at her sink in the kitchen washing breakfast dishes spoke out aloud saying 'Iana, kanna, saree, sareekanai, karaiakanna, kanaikarai, yahai, oh saramai, saramoiyaiianakanna'. ${ }^{8}$ The two researchers concluded that Mrs Rogers was speaking in tongues, assuming that her mother tongue was English. Upon further investigation they discovered that Mrs Rogers did not know what the words meant. However, she felt quite happy as she talked and sung the strange syllables. ${ }^{9}$

\section{Methodological approaches}

This research was conducted among Pentecostal-charismatic Churches in Botswana. Since it was not possible to carry out research in all Pentecostal Churches in the country, which are multiplying almost every day, we decided to carry out research in five selected Pentecostal-charismatic Churches. Their growth is attributed to a number of factors which include, among others, the theology of health and prosperity as well as the ability to speak in tongues - glossolalia. In our research we focused on the latter because it is considered by Pentecostal-charismatic Churches as the zenith of spiritual experience of people who are truly born again. Our research was conducted in Gaborone, the capital city of Botswana, in the following churches: Forward in Faith International; Full Gospel Church of God; Temple of Love Ministries; Divine Healing Ministry; and Christ Embassy. A word needs to be said about these churches.

In the first place, Forward in Faith International is one of the churches that have a long history in Botswana. According to Amanze (1994), this church was introduced in the country in 1974. When Amanze conducted research on this church, it had 250 members $^{10}$; however, our recent study shows that the church has more than 10000 members in Botswana. Full Gospel Church of God was established in Botswana in the 1960s. When Amanze did a study of this church, the total number of converts was $900 .{ }^{11}$ However, currently the church claims to have more than 50000 members. The Temple of Love Ministries was started in December 2008. By then, it had only four converts, but now the church has more than 50 members. The Divine Healing Ministry is one of the newly formed Charismatic churches. At its inception in 2006, it had fewer than 12 members; however, currently the church has grown to more than 150 converts. Christ Embassy, which was introduced in Botswana less than 10 years 
ago, is amongst the fastest growing Pentecostal-charismatic churches in the country. It has an approximate membership of 16000 people. $^{12}$

In carrying out our research in these churches, qualitative research methods were used to gather empirical data on the gift of speaking in tongues. We visited these churches several times on different Sundays between September and December 2011. Participant observation and interviews were some of the data gathering techniques employed in this study. The behaviour of the congregants during church worship was observed and was carefully recorded in our notebooks. We had ample opportunity to observe church members in their ecstatic state and frenzied excitement. We recorded various sounds that they produced which included hissing, vowels, consonants and others.

A total of 20 people were interviewed, four from each of the five churches where we conducted our research. Ten of them were males between the ages of 20 and 30 years. Ten were women also aged between 20 and 30 years. Eighteen of them had an equivalent of the Cambridge School Certificate, while two had a first degree from the University of Botswana. At the time of the interviews, all the respondents were regular members of their respective churches and had lived in Gaborone for more than 10 years. One of our respondents is a leader of his church and is a strong believer in the gift of speaking in tongues, which he believes to be 'divine language' and spoken by those who are born again and are destined to enter into the Kingdom of God.

In choosing our sample, we were interested in finding out whether education and living in the city had an effect in the way in which people perceive glossolalia. Responses from our respondents were written down in note books. Interview questions were both closed and open. Information was gathered on the peoples' understanding of speaking in tongues, their experiences when they are possessed by the Holy Spirit and whether they can interpret tongues. Beside interviews and participant observation, we also conducted literature-based research using various sources such as books, articles and online material. During fieldwork we followed the ethical code required when interviewing respondents. In this regard, we were requested not to reveal their names since they wanted to remain anonymous.

\section{Glossolalia in Christian tradition and in Pentecostal- charismatic Churches in Botswana}

The tradition of speaking in tongues in Christian churches goes back to the time of the inception of Christianity in Jerusalem in 33AD. It is based on the Pentecostal experiences as recorded in the Book of Acts 2: 1-4, which describes the coming of the Holy Spirit in the world on the Day of Pentecost. That event was characterised by the outpouring of the Holy Spirit on the Apostles during which they were able to speak in tongues. Various scholars have noted that speaking in tongues is not 
peculiar to Christianity but that it is also common in other religions. ${ }^{13}$ In this paper our focus is on the phenomenon of glossolalia as manifested and practised in JudeoChristian tradition. The issue of speaking in tongues is referred to in a number of Old Testament passages, chief among which is Joel 2:28-9 where it is written:

And afterwards I will pour out my Spirit on all people. Your sons and daughters will prophesy, your old men will dream dreams, young men will see visions. Even on my servants, both men and women, I will pour out my Spirit in those days.

Interestingly, it should be noted that though originally the text above did not make any reference to glossolalia, Pentecostals today take this to be one of the key theological texts that show that we now live in the era of the Holy Spirit as prophesied by Prophet Joel and that the Holy Spirit is available to everyone and the born again should be able to speak in tongues as a sign of being wholly connected with God and destined for eternal life in heaven. In the Apostolic period of the Christian era, glossolalia was in vogue and St. Paul makes repeated references to the same. It became a source of conflict and division in the church in Corinth where the congregation was divided between those who were able to speak in tongues and those who were not able to do so. Those who lacked the gift of speaking in tongues were despised by glossolalics as being not true Christians, something that prompted St. Paul to remind the believers that ecstatic utterance was by no means the only means by which the power of the Holy Spirit manifested itself in the Church. He observed that the Corinthians had too limited a concept of the Holy Spirit and reminded them that there are many gifts in the Church, but given by the same Spirit (1 Cor. 12: 1-11). He cautioned the Corinthians that speaking in tongues was not a passport to heaven and it was not a guarantee of the presence of the Holy Spirit, since the ecstatic phenomenon was similar to the kind of spiritual experience known to occur in pagan worship. ${ }^{14}$ During the Patristic period, Montanist communities spoke in tongues, experienced intense religious excitement and embraced martyrdom. ${ }^{15}$ They accused members of the mainstream Christianity of being unspiritual and of rejecting the Holy Spirit because of their failure to speak in tongues. ${ }^{16}$ Apart from the periods mentioned above, attempts to reconstruct the movement of speaking tongues in the other epochs of Christian history have found scanty evidence. ${ }^{17}$

In the twentieth century the phenomenon of speaking in tongues is traced back to W. J. Seymour, an Afro-American minister in the USA, who in 1906 through his sermons on the gifts of the Holy Spirit, particularly the gift of speaking in tongues, moved his congregation into frenzy to the extent that they began to speak in tongues. All this happened in a large old building at 312 Azusa Street in Los Angeles. This became the centre of Pentecostalism and hence of speaking in tongues. It is reported that after this religious experience, the centre attracted people from all over the world. When people returned home they founded similar Pentecostal groups. A great deal of emphasis was placed on the gift of speaking in tongues. ${ }^{18}$ According to Kildahl 
(1972), the Pentecostal doctrine is based on the fundamental belief that the full New Testament baptism in the Spirit is made manifest by glossolalia and that it is the will of God to pour out his Spirit in this manner upon all flesh. ${ }^{19}$ At the heart of this belief is that glossolalia is a true gift of the Holy Spirit and that it is the necessary evidence that one has received the baptism of the Spirit. ${ }^{20}$

The introduction of Pentecostal Churches in Botswana in the early 1960s and their proliferation in recent years brought along the gift of speaking in tongues as an authentic mark of being born again in the Holy Spirit and destined to eternal life. During our research in Gaborone, we got the impression that many of our respondents conceived glossolalia as a sign of being infused by the power of the Holy Spirit. During our visit to the churches that we studied we observed that believers, who were speaking in tongues, were acting and behaving in an unusual way. Some were falling down, crawling on the floor, and rolling over while others were beating their chests, clapping hands and shouting on top of their voices. The language they were speaking was incomprehensible, since it was made up of disconnected vowels and consonants. $^{21}$

When we interviewed them after church services, as reflected in the six case studies below, regarding their understanding of glossolalia, almost all of them believed that tongues are a gift from God given through the Holy Spirit. They testified that when the irresistible spirit of God comes down upon them, the power of the Holy Spirit flows deeper into their souls. This prompts them to speak in strange languages. Few of our respondents claimed that they can interpret tongues. The majority of them said that no one has the gift of interpreting glossolalia. They said that only the Holy Spirit knows the meaning of tongues. Our observation was that those who spoke in tongues were inconsistent in their understanding of tongues. Some believed that tongues were meant to confuse the devil who cannot understand glossolalia, while others believed that tongues are meant to edify individual believers, to give them joy and deepen their spirituality.

One of our respondents opined that tongues play a number of roles in the life of a believer. When a person is possessed and begins to speak in tongues, he/she can also prophesy. Some people can understand what is being said in tongues through the power of the Holy Spirit. Messages received through glossolalia are used to edify the life of the believers. Speaking in tongues takes place when people pray, sing and are engaged in other spiritual activities.

\section{Case studies of glossolalia in Pentecostal-charismatic Churches in Botswana}

This study is based primarily on fieldwork. The information is presented here in the form of case studies involving six respondents, three female and three male glossolalics, whom we selected as typical representatives of those who claimed that 
they have the gift of speaking in tongues. As noted above, the research was carried out in five Pentecostal-charismatic Churches. We shall look at each one of these in turn.

\section{Case study one: Temple of Love Ministries Church}

One of our case studies involved a woman from the Temple of Love Ministries which is situated in Gaborone West. She narrated to us that she normally gets possessed and speaks in tongues during worship. The power of God comes into her and flows deep into her soul. As a result, she prays and sings in tongues. When she is speaking in tongues she also receives revelations from God. Quite often, she speaks in tongues if something bad is about to happen to her or to a colleague. She informed us that when she speaks in tongues she demolishes the kingdom of the devil. Sometimes when she speaks in tongues she is able to interpret what God says to her in tongues. She believes that through the gift of speaking in tongues she will be able to heal the sick, cast out demons and prophesy. According to her, there is a close connection between speaking in tongues and prophecy, since the Holy Spirit brings these gifts to the believer. She noted that when she is speaking in tongues it is not she who is speaking but God who is speaking through the Holy Spirit. She reported that when she is possessed she can roll and crawl on the ground; often she cries and produces mucus from her nose. People can mistakenly think she is possessed by a demon. ${ }^{22}$

\section{Case study two: Divine Healing Ministry}

Another person we spoke to was a woman in the Divine Healing Ministries. She said she received the gift of speaking in tongues from the Lord. These strange languages are made up of consonants and vowels as follows: -baa-ba-aa, ra-a-ra-a, shalishasha-a-sha. Our respondent reported that she cannot interpret these languages. She also noted that there is no one in the church who can interpret glossolalia. She observed that when she speaks in tongues, she feels a lot of joy as the spirit of God flows in her. As a result, she sometimes laughs when the Spirit takes control of her. When she is possessed her actions are controlled by the Spirit of God. She merely becomes an instrument in God's hands under the control of the Holy Spirit. She informed us that when she speaks in tongues she can stop immediately if someone tells her to do so. She noted that the role of speaking in tongues is to edify the individual believer, though the tongue-speaker may not understand the meaning of what he/she says. ${ }^{23}$

\section{Case study 3: Forward in Faith International}

The third case study involved another woman in the Forward in Faith International Church. During our interview with her she noted that glossolalia is a heavenly language which is only understood by the Holy Spirit. Although she speaks in 
tongues, she cannot interpret them. She also indicated to us that there is no one in the church who has the gift of interpreting tongues. She intimated that the purpose of speaking in tongues is to show that the Holy Spirit is present in the life of the individual and it is there to edify the individual by strengthening him/her with hope of the future glory in God's Kingdom. She indicated that she feels a lot of joy when she is in the spirit and when the Spirit takes control of her she feels like flying to heaven. It is the Holy Spirit that makes her speak in tongues the language which she cannot interpret. She is not worried or bothered by her failure to understand the meaning of the languages she speaks when the Holy Spirit takes control of her. ${ }^{24}$

\section{Case study 4: Forward in Faith International}

This case study involved a male respondent in the Forward in Faith International. Our respondent told us that tongues are languages which Pentecostals prefer to communicate with God. They are meant to disturb the devil because he/she cannot understand tongues. Therefore, Satan's mission cannot be successful. He noted that when he speaks in tongues he feels that there is a serious interaction between him and God. He also feels the presence and the power of the Holy Spirit. Our respondent observed further that he cannot interpret tongues and argued that there are very few people who can interpret tongues - he has not seen anyone who can do so. ${ }^{25}$

\section{Case study 5: Christ Embassy Ministries}

One of our respondents was a man from Christ Embassy. He indicated that speaking in tongues shows that one is connected with God. When one speaks in tongues it shows that the Holy Spirit, who is the Comforter, is there for him/her. The role of glossolalia is to edify the speaker and testify to the presence of the Holy Spirit. When he speaks in tongues he is filled with joy. He believes that speaking in tongues is a testimony of what the saints will experience in heaven where they will have eternal life. He intimated that when he speaks in tongues it is not him who speaks but the Holy Spirit who speaks through him. His mouth and his body are used as an instrument. He noted that the Holy Spirit is like a drug. It takes control of everything. However, the believer remains conscious even though possessed by the Spirit. Our respondent lamented the fact that in some Pentecostal Churches believers are taught how to speak in tongues. To him this is un-Biblical. He further noted that though tongues are a language, they are not meant for instruction. They are not taught by anyone except the Holy Spirit. He indicated to us that he has not seen anyone with the gift of interpretation of tongues. It is only the Holy Spirit who knows the meaning of the tongues. As such tongues are spiritual, heavenly languages. ${ }^{26}$ 


\section{Case study 6: Full Gospel Church of God}

Our respondent from the Full Gospel Church was a man. He argued that glossolalia is real and that it is a gift from the Holy Spirit. He argued that a person cannot fake tongues. Tongues are an initial evidence of the spirit baptism. It is a spiritual experience. He observed that tongues cannot be understood by ordinary people. They can only be understood spiritually. He noted that when he speaks in tongues he feels out of himself. The feeling is very strange. One can cry, get excited, and laugh. As our respondent prayed, he uttered: Hiro---shi---shi-sha-a-karasha. He jumped and clapped his hands in excitement and charisma. He observed that if God allows a believer to speak in tongues there is a purpose for that. One can speak in tongues and interpret them at the same time. However, in his church there is no one who can interpret tongues. According to our respondent, tongues are intended to edify a person. Tongues are beneficial to the person who speaks in tongues. A person does not choose to pray in tongues. Tongues come through the Spirit of God. When speaking in tongues, it feels as if one has lost one's memory. It is as if one is drunk and the person seems to be psychologically disturbed. This is because of the power of the influence of the Holy Spirit. Tongues are a special visitation symbolising a further special touch of the Holy Spirit. ${ }^{27}$

\section{Our observations regarding the six case studies above}

At the end of our research we decided to analyse the case studies to see what they had in common. To our great amazement, we found that many of the statements our respondents made in regard to their spiritual experiences of speaking in tongues were described in psychological terms; that is, they made references to the state of their mind such as ecstasy, anxiety, fear, memory loss and the like. For example, a number of them said that when they speak in tongues they feel like 'flying' to heaven. In other words, they are overpowered with great excitement. In a number of cases our respondents noted that they speak in tongues when they are concerned that something bad is going to happen to them or their loved ones. In other words, there is an element of anxiety involved. We also noted that those who speak in tongues said that when they speak in tongues they display strange behaviour. For instance, they fall down, crawl on the ground no matter how dirty it is and roll over with tremendous speed as a whirlwind. At other times they jump and clap hands and move around hissing and making noise which may be awkward to those who do not understand the works of the spirit. In our observation this displays elements of spirit possession leading to some form of recognisable set of symptoms or behaviour associated in most cases with distress and interference with personal functions, which is a sign of mental disorder. ${ }^{28}$ At other times our respondents reported that when they are possessed they cry uncontrollably producing tears as well as mucus from their nose which, again, in our assessment is an element of psychological distress and at odds 
with the expectations of people's behaviour in Botswana culture, in which people are expected to control their emotions even after they have lost their loved ones. ${ }^{29} \mathrm{It}$ also came to our attention that sometimes the speakers laugh when the Holy Spirit takes control over them, which is an element of abnormal behaviour because it is not a typical or usual occurrence in everyday life, especially if there is no other person involved. ${ }^{30}$

Strange as it may sound, we observed that a number of our respondents spoke languages which were made up of disjointed vowels and consonants such as: $b a a$ baa, ra-a-ra, or shalisha-sha-a-sha or Hiro---shi---shi-sha-a-karasha which are basically meaningless sounds like the babble of infants. This is in line with the hypothesis of Crapps (1986) that glossolalia bears some resemblance to children's language. ${ }^{31}$ Since, in Pentecostal theology, speaking in tongues is a sign of being born again, when all things become new, it can be argued that from a psychological perspective this marks the beginning of spiritual rebirth marked by a language typical of childhood. ${ }^{32}$ Often the language spoken is not understood by the speaker and it is difficult to interpret either by the speaker himself/herself or by other people in the church, which conveyed an element of meaninglessness.

We also observed that in some instances there is a human element involved in glossolalia. For instance, some of our respondents noted that when asked to stop praying in tongues the worshipper can stop there and then, which shows that in speaking in tongues there is also an element of self-control. Not every action is controlled by the Spirit of God. We took cognisance of the fact that in some churches believers are taught how to speak in tongues, which shows that glossolalia can be learned and spoken as a result of pressure from a group to which one belongs.

At other times, the Holy Spirit was conceived as a drug. He takes control of everything. The connection between the Holy Spirit and drugs is a very interesting one. It is held that when the worshipper speaks in tongues it feels as if one is acting under the influence of drugs. It causes ecstasy in the mind. If this assertion is correct, then, from a psychological perspective, it becomes a matter of serious concern, because research shows that drugs (particularly psychoactive drugs such as alcohol, amphetamines, cocaine, ecstasy, marijuana, narcotics to name a few) act on the nervous system and alter states of consciousness, modify perceptions and change moods. It is held that continued use of psychoactive drugs can lead to tolerance and addiction. ${ }^{33}$ From our interviews we learned that when speaking in tongues it feels as if one has lost one's memory, in which case there is an element of memory loss. This also becomes a matter of grave concern. The importance of memory is crucial in the everyday life of individuals. Gross (2001) citing Blackmore noted that "without the capacity to remember...it is difficult to imagine what life would be, whether it could be called living at all. Without memory, we would be servants of the moment, with nothing but our innate reflexes to help us deal with the world. ${ }^{34}$

Finally, we noted one very positive element in glossolalia. We observed that after speaking in tongues the worshippers feel that they are in a world of happiness. 
This shows that glossolalia leads to joy and physical and spiritual well-being. On the basis of the above observations, we concluded that speaking in tongues involves a complex matrix of forces at work in the mind of the worshipper, which includes the presence of the Holy Spirit. The presence of the Holy Spirit, however, does not rule out the existence of other psychological elements possibly reinforcing one another. ${ }^{35}$

\section{Glossolalia from a psychological perspective}

As stated at the beginning of this paper, this is not a theological study of glossolalia but a study of the gift of speaking in tongues based on the psychological study of religion. Psychology has been formally defined as the scientific study of the behaviour of individuals and their mental processes. ${ }^{36}$ In this study we have employed the science of the mind and human behaviour to determine whether we can consider the gift of speaking in tongues as the language of God. Crapps (1986) indicated that glossolalics forsake typical language forms because they consider themselves to be grasped by the inexplicable God. Their aim is to overcome human language which they regard as a rational hindrance to genuine encounter with God and the sacred. ${ }^{37}$ Crapps (1986) succinctly describes it thus:

The worshiper, usually under the state of intense emotional excitement, utters a series of disconnected and unstructured syllables. Although the utterances exhibit vocalisation patterns that can be measured, they are non-communicative as language. The tongue-speaker uses ordinary vowel and consonant sounds, but strings them together haphazardly. Speed, volume and inflection may give the impression of sentences but decoding them and translating them are impossible...

In Pentecostalism glossolalia is an expected and highly desirable experience. It is available to all believers, the capstone of a progressively intense relation with God. In Pentecostalism salvation is perceived to come in three stages namely; regeneration, sanctification and baptism with the Holy Spirit. The last stage happens when the Holy Spirit comes down, takes up residence with a person and generates a blessed state of unimaginable ecstasy. ${ }^{38}$

From a psychological perspective, when a tongue-speaker is engaged in glossolalia, he or she is unable or cannot describe what happens in words but by analogy or figure of speech. This is typical of religious experiences. In the context of speaking in tongues, the believer can only say I have been baptised by the Holy Spirit and the necessary sign and ultimate assurance that such an event has taken place is glossolalia. This is considered as the ultimate or superlative gift of the Holy Spirit. At this point the words uttered and the language used is supposed to be the words and the language of the Holy Spirit and not the words of the believer. In Pentecostalism, speaking in tongues or glossolalia is considered a manifestation of the mind of the Spirit of God using human speech as a means of communication. ${ }^{39}$ It is interesting to note that this point was expressed by all our respondents in the study. Crapps (1986) pointed out that a Pentecostal describes the experience of speaking in tongues as a: 
Manifestation of the mind of the Spirit of God employing human speech organs. When man is speaking with tongues, his mind, intellect, understanding are quiescent. It is the faculty of God that is active. Man's will, certainly, is active, and his spirit, and his speech organs; but the mind that is operating is the mind of God through the Holy Spirit. ${ }^{40}$

Interestingly, this phenomenon seems to have also been noticed by those who studied glossolalia scientifically. For example, Kildahl (1972) indicated that when a person is speaking in tongues the ego (which is the conscious agent in the mind by which persons make choices and judgments) does not exercise control in the usual way. The tongue-speaker temporarily discards some of his or her ego functioning as it happens in such times as in sleep or in sexual intercourse. ${ }^{41}$ This phenomenon was also noticed in 2006 at the University of Pennsylvania, USA, by researchers under the direction of Andrew Newburg, MD who completed the world's first brain-scan study of a group of Pentecostal practitioners while they were speaking in tongues. The researchers noticed that when the participants were engaged in glossolalia, activity in the language centres of the brain actually decreased, while activity in the emotional centres of the brain increased. The fact that the researchers observed no changes in any language areas, led them to conclude that this phenomenon suggests that glossolalia is not associated with usual language function or usage. ${ }^{42}$ This seems to support the view that speaking in tongues should only be understood as a supernatural manifestation of the Holy Spirit.

Having said this, however, it should be noted that a good number of psychologists do not accept this line of argument. They dismiss the gift of speaking in tongues as psychoticism or severe neuroticism. ${ }^{43}$ This conclusion has been reached after observing the behaviour of tongue-speakers which cannot be described as ordinary or an everyday occurrence. When engaged in glossolalia, tongue-speakers, as we have seen in this study, tend to display abnormal behaviour. Such behaviour is only appreciated when it is explained theologically as an act of God in which case it is a matter of belief. ${ }^{44}$

It is interesting to note that as a result of what appears to be abnormal behaviour, as displayed in some of our case studies, a number of psychologists have attributed glossolalia to mental illness. Those who have stressed this perspective such as Pattison (quoted in Spilka, Hood, Hunsberger and Gorsuch 2003), claim that glossolalic individuals demonstrate 'overt psychopathology of a sociopathic, hysterical or hypochondriacal nature'. ${ }^{45}$ Kelsey (1964) in Speaking in tongues: An American experience noted that there is an implied correlation between glossolalia and schizophrenia, but rejected that the two are identical. He was more willing to see glossolalia as a lesser neurotic symptom but also doubted applying such a label to people who speak in tongues. ${ }^{46}$

It should be noted that modern researchers are taking a slightly different approach from the above by insisting that a distinction should be made between glossolalic behaviour and other superficial clinical parallels. The majority of clinical 
psychological and psychiatric professionals are inclined towards explanations that stress deviance..$^{47}$ In this regard, they are willing to see glossolalia as a lesser neurotic symptom and as a mild psychopathological disorder. Be that as it may, psychologists seem to be in agreement that there is evidence that speaking in tongues usually follows a period of crisis and works to resolve the resulting anxiety. ${ }^{48}$ This view is in line with Kildahl's (1972) contention that tongue-speaking does not take place in a vacuum. There are certain factors that lead people to speak in tongues such as anxiety caused by things such as marital difficulties, financial concerns, ill health and general depression. ${ }^{49}$

This explanation of glossolalia has led a number of scholars such as Preus (quoted in Spilka et al. 2003) to conclude that since speaking in tongues is a kind of 'release from tension' glossolalia should be described as an 'answer to personal stress and trauma' and that it can be accomplished by any person who wants to speak in tongues. ${ }^{50}$ What this basically means is that speaking in tongues is due to stress and it is a mechanism to cope with anxiety. In some research it has been found that more than 85 per cent of tongue speakers have experienced a clearly defined anxiety crisis preceding their speaking in tongues. Speaking in tongues has been found constructive and anxiety reducing. ${ }^{51}$ Glossolalia as therapy is associated with increased well-being, social sensitivity, resolution of neurotic conflicts and reduction of anxiety and tension. In this context glossolalia is a form of healing. ${ }^{52}$

To support this view, examples have been drawn from the Pentecostal experience which is said to have occurred during the time of very intense anxiety. The apostles had lived days of oppressive strain and waiting. Suddenly the floodgates of emotion were opened and a great revival occurred. Under the influence of this intense emotion some of the individuals started expressing their newly-found joy in either some real language which they knew but which was not their own, or in the kind of meaningless syllables that are used by other people today. ${ }^{53}$

A word of caution needs to be said here. It would be fallacious to think that glossolalics are different from other people in the community in terms of mental health. This point has been made poignantly by Kildahl (1972) who indicated that glossolalia is not necessarily a symptom of mental illness and that glossolalics suffer less stress. They have even gone further to note that the mental health of those who speak in tongues and of those who do not speak in tongues is equal. Both tonguespeakers and non-tongue-speakers are equal in their ability of doing things. On broad criteria of emotional well-being, tongue-speakers and non-tongue speakers are about the same. ${ }^{54}$ As a matter of fact, tongue-speakers are spread across the spectrum of metal health and illness and across the broad range of socio-economic status, intelligence and education..$^{55}$

One of the issues that have been raised in this study is whether we should consider glossolalia as a learned language. So far there is a pool of evidence that shows that glossolalia is, to a certain extent, a learned behaviour which is enforced in certain group settings into which glossolalic individuals are socialised. In such 
cases glossolalia has been found as performing the social function of integrating a glossolalic person into an approving religious group. Spamos (1987) in Glossolalia as a learned behaviour: An experimental Demonstration concluded that glossolalia is an acquired ability for which no real trance or Holy Spirit is needed. ${ }^{56} \mathrm{We}$, however, differ from this position. Our own view as theologians is that glossolalia is a gift from the Holy Spirit who uses human beings to edify the Church of God. Having said this, however, we admit that like any other spiritual activity, the Holy Spirit does not operate in a vacuum. He uses the faculties of human beings in varying degrees to achieve his goals, which are difficult to determine.

In three of our case studies above we learned that people have the ability to create a language that they can claim to be glossolalia and teach others how to use it. Kildahl and Qualben's research findings in 1972 revealed that speaking in tongues can sometimes be a result of a learnt experience acquired through being taught how to speak in tongues. During their research they noted that the language that the learners were taught to speak in, consisted of vowels and consonants strung together as follows: 'Aish nay gum nay tayo... aish nay um ...aish ...nay..anna..gayna ...ayna.. gannakeena. ${ }^{57}$ Argyle (2000) noted that linguistic analysis of this type of language found that there is no real language in glossolalia, since there is no vocabulary or grammar but a string of words like alleluia plus some biblical names. ${ }^{58}$ It should be borne in mind, however, that though it has been stated above that glossolalia consists of a stringing together of vowels and consonants, it does not necessarily mean that it is not a language at all. Kildahl (1972) is of the view that speaking in tongues is not gibberish. It has a rhythm and qualities of a language. ${ }^{59}$ People who speak in tongues may be aware of what is going on in the environment and yet at the same time there is some lessening of conscious control. ${ }^{60}$

\section{Conclusion}

In conclusion, this paper has examined the gift of speaking in tongues as practised in Pentecostal Churches in Botswana. The paper examined briefly the history of glossolalia in the church and its usage in Pentecostal Churches today. The study was based on six case studies in five Pentecostal Churches in and around Gaborone, Botswana. The various understandings of the meaning of glossolalia as perceived by glossolalics have been noted. These have been analysed from a psychological perspective. The various instances that lead to glossolalia were discussed. From a theological perspective we agree that glossolalia is a divine language and that through tongue-speaking God uses human agents to communicate with his people. From a psychological perspective, however, we seem to have challenges to conclude that glossolalia is a 100 per cent divine language. This is because in some instances, as this study has shown, glossolalia is a result of anxiety and other stresses of a social, cultural, economic and political nature. Again, the fact that in some cases the believers are taught how to speak in tongues, undermines the argument that when a 
believer is engaged in glossolalia all the activities at that point in time are controlled by the Holy Spirit. It appears to us that constant human interference in glossolalia undermines its very nature as divine language.

\section{ENDNOTES}

1. Argyle, M. 2000. Psychology and religion. London: Routledge, p. 138.

2. Crapps, R.W. 1986. An introduction to psychology of religion. Georgia: Mercer University Press.

3. Kildahl, J.P. 1972. The psychology of speaking in tongues. New York: Harper \& Row,

4. Kildahl, J.P. 1972. The psychology of speaking in tongues. New York: Harper \& Row, p. ix.

5. Kildahl, J.P. 1972. The psychology of speaking in tongues. New York: Harper \& Row, p. ix.

6. Allen, R. ed. 2000. The new Penguin English dictionary. London: Penguin Books, p. 594.

7. Allen, R. ed. 2000. The new Penguin...p. 594.

8. Kildahl, J.P. 1972. The psychology...p. 1.

9. Kildahl, J.P. 1972. The psychology...p. 1.

10. Amanze, J.N. 1994. Botswana handbook of churches. Gaborone: Pula Press, p. 104.

11. Amanze, J.N. 1994. Botswana handbook...p. 108.

12. Results of field work carried out between September and December 2011 in Gaborone Botswana.

13. Kildahl, J.P. 1972. The psychology...p. 11.

14. See Harvey,E.A. 1979. Companion to the New Testament. Cambridge University Press, p. 650 .

15. Dowley, T. 1977. The history of Christianity. Herts: Lion Publishing, p. 74.

16. Amanze, J.N. 1994. A history...p. 41

17. Kildahl, J.P. 1972. The psychology...p. 14-18.

18. Kildahl, J.P. 1972. The psychology...p. 18-19.

19. Kildahl, J.P. 1972. The psychology...p. 19.

20. Kildahl, J.P. 1972. The psychology...p. 22.

21. This phenomenon was observed in all the churches we conducted our research in the different dates as reflected in the case studies below.

22. Interview (hereafter int.) held at the Temple of Love Ministries, Gaborone West, 26/6/11.

23. Int. held at the Divine Healing Ministry, Gaborone, 12/6/2011.

24. Int. held at the Forward in Faith International Ministries on 12/6/2011.

25. Int. held at the Forward in Faith International Ministries on 12/6/2011.

26. Int. held at Christ Embassy Ministries-12/6/2011.

27. Int. held at the Full Gospel Church of God, Gaborone, 26/8/2011.

28. See Gross, R. 2001. Psychology: The science of mind and behaviour. London: Hodder 
and Stoughton, p. 636, where major categories of mental disorder as identified by DSMIV and ICD-10 have been discussed.

29. Personal observation for the past 20 years. People hardly cry that much during funerals as compared to people in Malawi, my native land, where there is a lot of wailing when death occurs.

30. See Gross, R. 2001. Psychology...p. 631, where one the definitions of abnormality is deviation from the average.

31. Crapps, R.W. 1986. An introduction...p. 352.

32. Meier, P.D. et al. 1991. Introduction to psychology and counseling. Kent: Monarch Publications, p. 256.

33. http://general-psychology.weebly.com-psych (accessed 2/5/2015).

34. Gross, R. 2001. Psychology...p. 244.

35. Personal observation.

36. Gross, R. 2001. Psychology. London: Hodder and Stoughton, p. 5.

37. Crapps, R.W. 1986. An introduction to psychology of religion. Georgia: Mercer University Press, p. 52.

38. Crapps, R.W. 1986. An introduction...p. 351.

39. Crapps, R.W. 1986. An introduction ...p. 350-1.

40. Crapps, R.W. 1986. An introduction...p. 351.

41. Kildahl, J.P. 1972. The psychology...p. 36-37.

42. http://psychology.wikia.com/wiki/glossolalia, accessed on 7/27/20011, p. 6.

43. Crapps, R.W. 1986. An introduction...p. 352.

44. Crapps, R.W. 1986. An introduction...p. 352.

45. Spilka, B. et al. 2003. The psychology...p. 513.

46. Kelsey, M.T. 1964. Tongue speaking: An American experience, New York: Doubleday, p. 513.

47. Spilka, B. et al. 2003. The psychology...p. 513.

48. Spilka, B. et al. 2003. The psychology...p. 513.

49. Kildahl, J.P. 1972. The psychology...p. 57.

50. Spilka, B. et al. 2003. The psychology...p. 513.

51. Spilka, B. et al. 2003. The psychology...p. 514.

52. Spilka, B. et al. 2003. The psychology...pp. 526-7.

53. Pratt, J.B. 1924. The religious consciousness: A psychological study, New York: The MacMillan Company, p. 185.

54. Kildahl, J.P. 1972. The psychology...p. 48.

55. Kildahl, J.P. 1972. The psychology...p. 49.

56. Spamos, N. 1987. Glossolalia as a learned behavior: An experimental demonstration, p. 5.

57. Kildahl, J.P. 1972. The psychology...p. 2-3.

58. Argyle, M. 2000. Psychology and religion, London: Routledge, p. 138.

59. Kildahl, J.P. 1972. The psychology ...p. 2.

60. Kildahl, J.P. 1972. The psychology...p. 2. 


\section{LIST OF REFENCES}

Allen, R. ed. 2000. The new Penguin English dictionary. London: Penguin Books.

Amanze, J.N. 1994. Botswana handbook of churches. Gaborone: Pula Press.

Argyle, M. 2000. Psychology and religion. London: Routledge.

Crapps, R.W. 1986. An introduction to psychology of religion. Georgia: Mercer University Press.

Dowley, T. ed. 1990. The history of Christianity. Oxford: A Lion Handbook.

Gross, R. 2001. Psychology. London: Hodder and Stoughton.

Harvey, A.E. 1979. Companion to the New Testament. Cambridge University Press.

Kelsey, M.T. 1964. Tongue speaking: An American experience. New York: Doubleday.

Kildahl, J.P. 1972. The psychology of speaking in tongues. New York: Harper \& Row.

Pratt, J.B. 1924. The religious consciousness: A psychological study. New York: The MacMillan Company.

Spamos, N. 1987. Glossolalia as a learned behaviour: An experimental Demonstration.

Spilka, B., R.W. Hood, B. Hunsberger and R. Gorsuch. 2003. The psychology of religion: An empirical approach. New York: Guilford Press.

Internet Sources

http://psychology.wikia.com/wiki/glossolalia, 7/27/20011, p. 5.

http://general-psychology.weebly.com-psych (accessed 2/5/2015). 